Social exclusion, youth transitions and criminal careers: five critical reflections on 'risk'

Prof. Robert MacDonald

Youth Research Group,

School of Social Sciences and Law,

University of Teesside,

Borough Road,

UK TS1 3BA.

Email: R.MacDonald@tees.ac.uk

\title{
Biographical note
}

Robert MacDonald is Professor of Sociology at the University of Teesside, UK. He has studied young people and youth issues for several years. Most recently he has coauthored Poor Transitions: Young Adults and Social Exclusion (2004, Policy Press) and Disconnected Youth? Growing Up In Poor Neighbourboods (2005, Palgrave). 


\title{
Social exclusion, youth transitions and criminal careers: five critical reflections on 'risk'
}

\begin{abstract}
This paper draws upon recent youth research in some of Britain's poorest neighbourhoods (in Teesside, North East England). It stresses the importance of a qualitative, biographical and long-term perspective in attempting to understand drugusing and criminal careers (and wider youth transitions) and points to some difficulties in applying - straightforwardly - influential models of risk assessment and prediction to individual biographies.
\end{abstract}

In a context of deep, collective disadvantage, most research participants shared many of the risk factors associated with social exclusion in early adulthood. Yet the majority did not pursue full-blown criminal or drug-using careers and the research struggled to identify background factors that seemed to play a causal role in separating out more 'delinquent' transitions from more 'conventional' ones. Youth biographies were marked by flux; they did not roll on deterministically to foregone conclusions. Unpredictable 'critical moments' turned transitions in unpredictable directions; sometimes towards crime, sometimes away. The paper concludes that there is danger in criminal career research as in studies of youth transition - in prioritising individual level explanations at the expense of an assessment of the 'risks' presented by socio-spatial and historical context. 


\section{INTRODUCTION}

This paper reports recent studies from some of the poorest neighbourhoods in Britain in Teesside, North East England - that sought to understand young people's biographies qualitatively, holistically and longitudinally. Their close-up description of the experience of growing up here enabled critical examination of popular, controversial theories that claim to capture these processes of transition (i.e. theories of 'the underclass' and 'social exclusion'). The research was therefore not designed to be, exactly or solely, a study of youth offending or criminal careers and even less so an assessment of important theories of risk prediction and management in respect of these. Nevertheless, it does suggest some useful, critical questions about the application of risk assessments and predictions to individual young people as their lives unfold.

The paper begins by outlining our theoretical take on debates about youth transition and goes on to describe, in brief, our research methodology. The dominant, social scientific approach to understanding criminal careers and risk is then outlined. This is followed by a sketch of criminal and drug-using careers as uncovered in our research in Teesside. This is used to raise five, critical reflections on orthodox, risk-based paradigms.

\section{A NOTE ABOUT YOUTH TRANSITIONS}

The value of the concept of transition (and alternative metaphors such as 'pathway') has been hotly contested in youth sociology. Because the movement to adulthood has become more fragmented and unpredictable (Du Bois-Reymond, 1998; Cohen and Ainley, 2000; EGRIS, 2001), critics have distanced themselves from structurally-oriented, class-based analyses of youth transitions in favour of theories about individualisation and the Risk Society (Giddens, 1990, 1991; Beck 1992; Beck et al, 2004).

It is true that since the 1970s youth transitions in the UK have become more complicated, extended and apparently less class-bound. This does not, however, invalidate the concept of transition (see MacDonald and Marsh, 2005 for fuller discussion). As Furlong and Cartmel (1997) and Roberts (2000) show, a young person's opportunities and destination are still strongly influenced by original class location, even though the choices and risks of restructured transitions tend to engender a greater sense of individual autonomy. Thus, summarising much recent UK youth research in the UK, 
Jones (2002) stresses the hardening up of 'the youth divide'. Those (typically workingclass) young people that make the speediest transitions into the labour market, to parenthood and to independent living face greater risks of the negative outcomes associated with social exclusion.

In drawing upon the sociological concept of 'career' (Becker, 1963; Berger and Berger, 1972), our studies in Teesside have explored the way that individual decision-making, informed by young people's cultures and sub-cultures, interacts with socially structured opportunities to create individual, and shared, paths of transition. Coles $(1995,2000)$ broadens the scope of transition studies to include 'family careers' (the attainment of relative independence from family of origin) and 'housing careers' (the move away from the parental home) alongside the study of 'school to work careers' (educational and employment experiences). In some contexts 'criminal careers', 'drug-using careers' and 'leisure careers' can also become important in shaping youth transitions (MacDonald and Marsh, 2005, explains these terms). These six 'careers' became the focus of our interviews with young people.

\section{The Teesside studies}

This paper is based on three studies that shared similar aims, research sites and methods

${ }^{1}$. The first of these was published as Snakes and Ladders (Johnston et al, 2000). It was interested in how 15 to 25 year olds (n. 98) from the same neighbourhood ('Willowdene' in the town of 'Kelby', Teesside), and sharing the same class and ethnic backgrounds, evolved 'alternative' and 'mainstream' transitions to adulthood. The second study Disconnected Youth? (MacDonald and Marsh, 2005) - examined controversial underclass theories and concepts of social exclusion and their connection with the lived realities of 15-25 year olds (n. 88) who were growing up in the poor neighbourhoods of 'East Kelby'.

\footnotetext{
${ }^{1}$ Whilst this paper is individually authored it is based on the research and analysis of a wider team. Particular thanks go to the key fieldwork researchers - Paul Mason, Jane Marsh and Donald Simpson - and to Tracy Shildrick and Colin Webster for their insightful thinking on our shared questions, to the Economic and Social Research Council and Joseph Rowntree Foundation for funding and to the research participants. All real names of people and places have been anonymised. Space disallows further discussion of the methodological design and details of these studies: see Webster et al (2004), MacDonald and Marsh (2005) and MacDonald et al (2005).
} 
In the late 1990s, the seven wards of these studies featured in the top five per cent most deprived nationally (DETR, 2000) and two of them were in the worst five - of 8,414 - in England. Both projects involved periods of participant observation and interviews with professionals who worked with young people. At their core, though, they relied on lengthy, tape-recorded, biographical interviews (Chamberlayne et al, 2002) with a total of 186 young people (82 females and 104 males) from the predominantly white, (ex) manual working-class population resident in 'one of the most de-industrialised locales in the UK' (Byrne, 1999: 93).

There is not the room here to review these studies' findings. We note only that whereas at the level of the individual case informants described differentiated family, housing, leisure, criminal and drug-using careers, they were united by a common experience of economic marginality. The majority displayed highly conventional attitudes to employment but their late teenage years school-to-work careers struggled to progress beyond low paid, low skill, insecure 'poor work' (Byrne, 1999).

Our most recent study, Poor Transitions (Webster et al, 2004), carried out in 2003, was designed as a follow-up to the two, earlier ones. Where did such transitions lead individuals in there mid to late twenties? Were people eventually able to carve out more progressive transitions, even in unpromising circumstances? Or were longer-term problems of social exclusion cemented in place by early experiences of economic marginality?

We chose to re-interview 34 individuals (18 females and 16 males), drawn from the two original samples, who were now aged 23 to 29 years. We sampled theoretically so as to understand better the longer-term transitions of: young women who, at last interview, had been committed to full-time parenting (n. 11); those with enduring but unrewarding commitment to education, training and employment (n. 11); and individuals seriously involved in criminal and/ or drug-using careers (n.12).

Our analytic approach combines standard, qualitative analysis of recurrent and divergent themes and responses across the sample(s) and longitudinal analysis of individual, retrospective biographical interviews from all three projects. In doing so, we present research that is relatively unusual in contemporary British social science. Not only are the 
nearly two hundred participants often described as 'hard to reach' (Merton, 1998), they allowed a rare, close-up insight into the ways people at the sharp end live through conditions of social exclusion.

\section{YOUNG ADULTS, RISK \& CRIME}

At a general, social theoretical level, theories of risk, individualisation and the Risk Society have had considerable impact on youth studies (e.g. Furlong and Cartmel, 1997; France, 2000; Mitchell et al, 2004). More particularly, 'the risk factor paradigm dominates a range of policy developments and is seen by many agencies as the solution to the "youth problem"” (Crow et al, 2004: 73). Coles (2000) provides a useful critical summary of risk approaches to teenage pregnancy, unemployment, mental health and 'NEET' (i.e. young people who are not in education, employment and training).

One of the most influential examples of the risk approach in youth studies is the criminal career perspective. Its key exponent in the UK - and 'globally' according to Muncie (2004: 277) - has been David Farrington. The theoretical promise, and policy influence, of this type of criminology is that offenders and offending can be predicted, known and controlled $^{2}$. Farrington concludes that a small group of chronic offenders is responsible for a large proportion of crime and that 'these chronics might have been identified with reasonable accuracy at age 10' (1994: 566). Longitudinal, quantitative studies (usually of young men) are used to identify, measure and model the early life influences on offenders. Individual psychopathology, from an early age, predicts later forms of antisocial behaviour and crime:

...hyperactivity at age 2 may lead to cruelty to animals at 6 , shoplifting at 10 , burglary at 15 , robbery at 20 , and eventually spouse assault, child abuse and neglect, alcohol abuse, and employment and accommodation problems later on in life. Typically, a career of childhood anti-social behaviour leads to a criminal career, which often coincides with a career of teenage anti-social behaviour and leads to a career of adult anti-social behaviour (Farrington, 1994: 512).

The 'major risk factors for juvenile offending' (Farrington 1996: 2-3) range through individual personality and intelligence, parental supervision, parental conflict and separation, school, peer and community influences and socio-economic status. This

\footnotetext{
${ }^{2}$ Other studies that operate with a less deterministic theory of criminal career and/ or give a more sociological account of such careers include Sampson and Laub (1993), Laub and Sampson (2003) and Craine (1997).
} 
positivist, 'actuarial' approach to crime (see Young, 1999) has found favour in youth policy and practice interventions. A good example can be found in the Communities that Care programme for reducing anti-social behaviour (e.g. Beinart et al, 2002). Devised in the United States, it has been imported to the UK with major funding from the Joseph Rowntree Foundation. It aims to 'tackle risk factors that are problematic within particular communities' (Farrington, 1996: 5). Crow et al's evaluation (2004) highlights the severe difficulties that have been faced in implementing this model in practice.

The same stress on detecting risk factors amongst the young and intervening to ward against the predicted, later outcomes is central to the British government's youth crime strategy (see Home Office, 2004: 41). It is evident in the 0ASys system of offender risk assessment and prediction operated by the Probation Service (Horsefield, 2003) and in the programme of Youth Inclusion Projects (YIPs) ${ }^{3}$, wherein local, multi-agency teams identify and work with those 50 young residents of high crime areas at greatest risk of offending (even if some individuals have, in fact, no record of offending at that point).

\section{A SKETCH OF CRIMINAL AND DRUG-USING CAREERS ON TEESSIDE}

Ours were not statistically representative samples of young people in these neighbourhoods but interviewees' biographical accounts did help us sketch out the nature and shape of criminal careers. Whilst proportions of interviewees with criminal involvement differed a little, the Snakes and Ladders and Disconnected Youth studies came to very similar theoretical descriptions of criminal careers ${ }^{4}$.

Just over half of the 88 young people in the latter project had committed a criminal offence on at least one occasion. For the majority of these, however, their 'criminal careers' were limited, typically to one-off, petty shop-lifting in their early to mid-teenage. For most, their transgressions ceased there. Two key movements can be identified in the consolidation of the most serious, longer-term criminal careers (of the sort displayed by 20 interviewees).

The first of these was the hardening up of school disaffection (again, a common experience of the samples overall) into full-blown educational disengagement, usually

\footnotetext{
${ }^{3}$ See www.crimereduction.gov.uk/gpyc05.htm - accessed 21 st October 2004.

${ }^{4}$ Other publications provide a more detailed account. There is not the space here, for instance, to discuss the role of gender in shaping the forms, prevalence and content of criminal careers amongst our samples.
} 
displayed in frequent, persistent truancy. Simultaneous disengagement from school and engagement with 'street corner society' further established oppositional identities and was the cornerstone for the evolution of most careers of crime that extended beyond early to mid-teenage:

...just me and this other lad used to nick off all the time...Just go and hang about the town...that was me starting days of crime and that, yeah...shoplifting and pinching bikes, that's what it was.

Danny (21, Young Offenders Institute inmate).

Dull truant time was enlivened by the camaraderie of shoplifting jaunts, other petty thieving and speeding around the estates in stolen vehicles: crime as leisure for bored, out-of-school teenagers. Although 17 year old Richy said that he had often 'mooched [stolen from garden] sheds', he did not consider himself 'a bad lad, a real thief'.

Acquisitive crime did raise cash but the main motivation was to relieve boredom: 'when you pinch summat, like a barbecue set you can sell on for $£ 10$, you can buy yourselves a few bottles of cider, can't you? You can cure your boredom then' (see Stephen and Squires, 2003).

For some, this marked the early phases of criminal apprenticeships. They began to learn the routines of acquisitively oriented offending (e.g. how and what to thieve from cars) and were drawn into local criminal markets (e.g. where to fence stolen property, the market rate for 'knock-off gear', etc.). For many, though, these sort of infringements coupled with underage drinking and recreational drug use - marked the extent, and endpoint, of criminal careers.

Thus, the large numbers involved in (petty) offending in early teenage lessened as the years passed. The second, most significant moment - that helped to drag out a smaller number of individual's criminal career into later years and to transmute them into something more destructive - is when heroin enters the scene. Local police and drugs workers reported how cheap, smoke-able heroin flooded into Teesside's working-class housing estates in the mid-1990s, prior to which there had been a negligible local heroin using population. Teesside's young people seem unprepared to resist the temptations of this 'poverty drug' and made speedy transitions from occasional, recreational use of drugs 
such as cannabis to often daily, dependent use of heroin (and later in the 1990s, crack cocaine).

For this minority of interviewees (n. 11 from 88 in the Disconnected Youth study), dependent use of heroin was the driving force behind exclusionary transitions which distanced them from their families, their previous life-styles, from the labour market and which entangled them in chaotic, damaging careers of drug-driven crime (see Simpson, 2003). Heroin use became central to an understanding of their unfolding biographies.

For individuals like Richard, desperate acquisitive criminality was fuelled by the need for daily drug money. By the age of 20 , this close combination of drug and crime careers had progressively closed down options for a more 'mainstream' lifestyle. He had failed to complete several training programmes, been employed only once - briefly, been unemployed recurrently, become estranged from his family, been homeless, had a lengthy, worsening record of offending and had been imprisoned twice. He was living in a bail hostel, struggling to remain committed to a methadone programme and scratching around trying to find ways, beyond heroin, to fill tedious, direction-less days. Questions can be asked about the descriptive purchase provided by the concept, but if anyone is 'socially excluded', Richard is.

Yet our follow up study (Webster et al, 2004) produced some surprises. Richard was one of those re-interviewed for Poor Transitions, three years later. The intervening period had seen a familiar pattern of heroin use, offending, prison, desistance and relapse to heroin use. He said:

It's like a vicious circle. It's like one, big, magnetic circle... when you get out of jail it starts again. You're slowly getting drawn back in all the time... back on the circle again, moving round and round and back in the same direction all the time.

At the most recent interview, Richard - like most in this sub-group in the follow-up study - was in a state of 'fragile desistance' from crime and dependent drug use. By this we mean that we agreed that he was making a sustained, genuine and - at that point apparently successful attempt to take the long, arduous, risk-laden struggle back to 'a normal life', as he described it. We stress the fragility of desistance as a process (rather than a single, simple event) because the biographies of this sub-sample were replete with failed 
attempts and because success was contingent on several factors beyond individual motivation.

Just as the perceived purposelessness of school was the context for the drift into offending - and later unemployment meant informants sometimes went down 'the wrong path' into more serious crime - the availability of purposeful activity in which individuals could invest their time, energy and identity aided this 'fragile desistance'. This purposefulness could be found in normal aspects of youth transition and, confirming other criminological research, the getting of jobs, the forming of new partnerships and becoming a parent motivated and facilitated the process of 'growing out of crime' (Rutherford, 1992). The problem, though, is that a corollary of sustained, heroin-driven crime is often largely 'empty' school-to-work careers punctuated by repeated spells of imprisonment. This makes the achievement of these sorts of resolution much harder. People like Richard are unlikely to appear attractive as potential employees, partners and fathers. With purposeful activity to engage energies and through which to redefine personal identity, liberating oneself from addiction was hard enough. Without it, relapse was common. Heroin helped 'fill the void [and] make life bearable' (Foster, 2000: 322).

Easy access to therapeutic, non-punitive drug treatment services was also a significant aid to desistance, as was physical and emotional detachment from earlier sub-cultural lives and alliances. Dependent heroin users were unanimous on this point; their lives since mid-teenage had been lived within social networks that reinforced drug behaviour. Imprisonment sometimes provided a welcome opportunity to do 'get clean' (albeit under a harsh, non-therapeutic regime). A few had even purposefully sought a custodial rather than a community-based sentence as a way of escaping the recurrent drug temptations they encountered 'on the street'. Prison release signalled a return to the environment that had generated initial drug dependency and was often viewed with trepidation: 'you're just going back to the same place, the same group of people and it's easy to get back into it (Stu, 20).

\section{FIVE CRITICAL REFLECTIONS ON THEORIES OF RISK \& CRIMINAL CAREER}

It is important to re-iterate that our research was not designed to evaluate risk assessment approaches in relation to offending. It could not, for instance, include any proper measure of important risk factors such as parental supervision (McVie, 2004). It did 
confirm empirical findings from larger, more statistically representative studies (e.g. gender as an influence on offending and the factors that aid desistance). Our studies do not cast doubt on the importance, influence and rigour of studies on risk and criminal career but do suggest, we believe, some useful theoretical and methodological questions for such approaches and for their application in policy and practice.

Firstly, we should be wary about presuming a tight, causal fit between particular risk indicators and later, or concurrent, behaviour. For instance, the research literature (e.g. Graham and Bowling, 1995) and our own studies suggest a strong association between persistent school truancy and offending. According to our evidence, however, the first did not determine the second (as implied by the Social Exclusion Unit, 1997). The majority (n. 16) of those with more sustained, criminal careers (n. 20) in the Disconnected Youth sample had been frequent school truants. Yet a substantial minority (n. 14) of frequent truants (n. 40) reported no offending whatsoever. Talking of the risk factor approach, Coles (2000: 194) worries that:

... [it] employs a remarkably 'deductive', 'positivistic' and 'normative' approach to problem identification and problem solving. It suggests that social science is supremely confident that it knows the causes of problem behaviours and poor outcomes during youth transitions. This might be a very questionable assumption.

Secondly, our studies struggled to identify any earlier single, individual or family-level factor that would predict confidently those who would follow 'delinquent' transitions. According to our research evidence, those in these studies with the most persistent, extensive later criminality could not have been identified with reasonable accuracy at age 10' (Farrington, 1994: 566). The samples as a whole shared many socio-economic (i.e. low socio-economic class), educational (e.g. poor school performance) and family (e.g. parental separation, bereavement) risk factors. These were not, however, able to explain why a minority of individuals pursued criminal careers and a majority did not. Of course, proponents of risk factor approaches would stress that theirs are theories that suggest (or are meant to suggest) probabilistic, general associations between risks and later outcomes that might, therefore, not be applicable to individual cases ${ }^{5}$.

Webster's analysis of the combined 'data' from the Snakes and Ladders and Disconnected Youth studies does confirm 'the link between having experienced risk factors and being a 
frequent offender' (2005: 5). What he means is that the majority of the latter 'possessed' more of the former (i.e. frequent truancy, family conflict, no qualifications, troubled backgrounds) than those who had never offended. As such, on this point, it may be that there is no substantial disagreement between orthodox criminal career research and our findings. Nevertheless, whilst academic proponents of risk factor approaches rightly tend to demur from using risk factors to predict individual behaviour this is not always the case with some of the policy and practice outcroppings of risk theory. As noted earlier, the offender risk assessment system used by the UK Probation Service and the British government's programme of Youth Inclusion Projects do exactly this. Furthermore, the fact that around a third of non-offenders in our studies also shared the same type and number of risk factors as the frequent offenders raises interesting questions, we think, about the level of probable effect of risk factors and their relationship to later outcomes. One such question concerns the uneven distribution of 'protective' factors against risk, which might help explain why some do not follow the 'probable' path to crime. Farrington (1996: 3) notes that 'comparatively little attention' has been paid to these, especially amongst 'those from high-risk backgrounds' (see Scott and Chaudhary, 2003) ${ }^{6}$.

This problem of how to explain why some people with a heavy burden of criminogenic risk factors do not evolve criminal careers is also identified by Smith and McVie (2003: 170): 'the substantial limitation' of childhood risk predictions is 'that there are many "false positives"... [for example] among children who are difficult to control there are many who turn out not to have criminal careers as adolescents or adults'.

Contrary to some theorisations of crime in poor neighbourhoods (e.g. Dennis, 1994; The Guardian 5 April 2001), for instance, the Disconnected Youth study found no association at all between family type and later criminality. Only four of those 20 who reported frequent, longer-term offending were brought up in lone parent families. Interviewing siblings who followed quite different paths confirmed our wariness about the 'actuarial positivism' present in some contemporary criminology (Young, 1999) ${ }^{7}$. Many were called, but few were chosen. Long-term educational dis-engagement and engagement

\footnotetext{
${ }^{5}$ As did a very helpful, anonymous, critical reviewer of this paper.

${ }^{6}$ And this question is one that we are attempting to interrogate more closely in future analysis and writing.

${ }^{7}$ Farrington and Painter's (2004) study of the siblings of the offenders in the Cambridge Study in

Delinquent Development also raises queries. (Only) 44 per cent of brothers and 12 per cent of sisters had a
} 
with street-based peer groups was a necessary condition for the evolution of serious criminal careers but it was not a sufficient condition ${ }^{8}$.

Thirdly, which of the multitudinous risks experienced by our samples might be most significant? Which risks propel some young people towards crime (and which do not)? Sorting out 'which risk factors have causal effects' is a 'difficult question', but Farrington and Painter (2004: 57) go on to suggest that 'if all modifiable risk factors are targeted' by intervention programmes they 'will be effective because at least some of the risk factors will be causes'. The current UK ESRC research network on Pathways in and out of crime also highlights the theoretical 'difficulty in attributing causality to single and universal "risk" factors. For example, life-histories show that the same "factor" can have different consequences for different people at different times' (ESRC, 2004: 3). The Teesside studies go further: the same risk factor can have quite different consequences for the same individual, at different points in the life-course. For instance, Poor Transitions (Webster, et al, 2004) shows how in the biography of one young man, the deaths of close family members became, at different points, the major psychological triggers for the turn to and turn away from heroin.

This leads us to our fourth, critical reflection on risk orthodoxies. Methodologically, large-scale, quantitative studies of criminal careers help show co-relations between a range of variables and outcomes across larger, representative samples. They are less able than qualitative studies to get close up to social actors' own subjective, complicated accounts and life stories ${ }^{9}$. Although class, ethnicity and place united these interviewees, their subjective experiences of transition were different. The combined influence of schoolto-work, family, housing, leisure, criminal and drug-using careers meant that individual transitions were complex, fluid and unpredictable. Biographical interviews highlighted the

conviction despite the fact - presumably - that these siblings shared many of the same risk factors as their offending brothers.

${ }^{8}$ We are unable to say much about early childhood behaviours, personality types or the sort of parenting that interviewees had received. These risk factors might explain involvement in criminal careers amongst our sample. It is possible but unlikely, however, that the rate and form of youth offending in Teesside in the 1990 s can be explained by a sudden change in local parenting styles or preponderance of anti-social personality types (Smith and McVie, 2003).

${ }^{9}$ For instance, when non-offenders were pushed about why they, as individuals, were not criminally inclined they reached for shorthand versions of underclass theory: 'bad' parents produced 'bad' children. This was sometimes despite the facts of their own family history (e.g. of siblings who had become embroiled in crime) and of their own, occasional offending. Stronger evidence against the 'bad parenting/ bad parents' thesis is the fact those interviewees who had been involved in serious offending also described, remorsefully, their own parents' conventional morality and heroic, failed attempts to keep them on 'the straight and narrow'. 
significance of contingent, unpredictable events and experiences in the creation of youth transitions of different sorts. 'Youth' is emphasised here because, like Smith and McVie (2003), we are interested in post-childhood influences on criminal careers (such as the role of leisure lifestyles and social networks: see also Wikstrom, n.d.; Armstrong, 2003). Criminal - and non-criminal - destinies are not set in stone in childhood. Teenage and young adulthood presented unpredictable 'critical moments', with unpredictable consequences for some transitions (Johnston et al, 2000; Thomson et al, 2002) ${ }^{10}$. Events and encounters in one sphere could have dramatic repercussions in another. 'Stuff happens' and more 'stuff happens' as the years pass, remarks Webster (2005: 1). Physical and mental ill health was widespread amongst interviewees and their families, unsurprisingly so given what we know about the socio-spatial concentration of health inequalities (Mitchell et al, 2000). Experiences of loss - particularly of bereavement and parental separation - proved to be especially important in shaping the course of individuals' lives thereafter.

Again, though, how such events impact on transitions would be unknowable without the benefit of interviewees' retrospective biographical accounts. Seemingly following uneventful, 'normal' transitions until that point, a few interviewees highlighted family traumas as the moment when they started 'going off the rails'. Learning her 'father' was not actually her father at the age of 11 was identified by Sarah as the 'turning point' (Hodkinson and Sparkes, 1997) that set in train a series of turbulent relationships with family members and, later, boyfriends, which in turn motivated a very chaotic, nomadic housing career. Conversely, Martin is a good example of a person who, despite multiple personal hardships ('risk factors'), such as the suicides of his best friend and father when Martin was in his late teens and, later, the peri-natal death of his first child, remained steadfastly committed to a 'conventional' working-class life-style.

Fifthly, and finally, there is a tendency in much criminal career research to overplay individual-level risks at the expense of those that are presented by the historical and spatial contexts in which youth transitions are made (Smith and McVie, 2003). According to our research, it would be impossible to understand the contemporary criminal careers of disadvantaged youth in Teesside without reference to two, crucial historical-spatial

${ }^{10}$ For instance, traumatic critical moments sometimes spurred desistance and caused people to re-orient their lives. Lisa used to be 'in with a crowd getting into trouble and doing drugs' until she was raped by one 
processes (Webster et al, 2006). The first is the rapid and widespread de-industrialisation of this locale (Byrne, 1999) and the concomitant rise of economic marginality and poverty for working-class youth. Talking of our research, Webster (2005: 1) puts it like this:

...our cohorts were born on the cusp or in the depths of accelerated social transformation (i.e. between 1974 and the mid-80s), which de-industrialised and destabilised their neighbourhoods, polarising their experiences and class positions. These crises were shifted onto the life histories of individuals.

The second is the historically unprecedented influx of cheap heroin in the mid-1990s. The testimonies of drugs workers, police officers, adult residents and young people all pointed to the devastating, localised and recent effects of 'poverty drugs' in enmeshing some young people in the most damaging forms of criminal career. Prior to the mid-90s, it would have been difficult to locate any individuals who had the sort of transition described by Richard (earlier). In other words, new, imported risks bear down on young people's lives here; risks which were unknown just a few years earlier and which are 'scarcely recognised in risk and prediction studies' (Webster et al, 2006).

Of course, it would be foolish to argue that persistent youth crime is always and has always been rooted in drug dependency. Craine (1997) shows how economically marginal transitions can readily generate minority 'alternative careers' of crime, regardless of any contact with 'poverty drugs'. Nevertheless, the form of drug-crime career sketched in this paper explains much of, and the most pernicious examples of, current youth offending in this locale. The implication of this argument is that in emphasising childhood experiences and ingrained personality factors, criminal career research can underestimate the influence of changing community conditions (specific to particular places and times) and how these are encountered in youth transitions in generating the most serious forms of criminal career ${ }^{11}$.

of them. Zack explained how 'the turning point' in his life was when 'my best mate hung 'imself. He had now 'calmed down now' and given up 'all sorts of mad stuff.

11 Webster (2005: 2) asks:

Has political expediency and scientific attrition narrowed down risk factors to the family, parenting, truancy and peer groups because these individualised factors are amenable to early micro interventions, thus ignoring the more intractable influences of social exclusion and neighbourhood destabilisation resulting from social and economic change? 


\section{SUMMARY AND CONCLUSION}

In making their transitions, our interviewees collided with the numerous hardships of socially excluded, poor neighbourhoods. Direct, cumulative experience of, inter alia, poverty, personal and family ill-health, criminal victimisation, unemployment, poor schooling, offending, problematic drug use and homelessness undeniably affected the sort of lives they led. These were the sort of risks allotted to young people born in these neighbourhoods during the latter part of the twentieth century. Exactly what sort of effects such experiences had, at the level of individual transitions, was much less certain. 'Stuff happens' (Webster, 2005: 1) - sometimes for the better, sometimes for the worse and sometimes with unclear, equivocal outcomes. A key conclusion of these studies is, then, about the contingency of life biographies: transitions of whatever sort - whether they be 'conventional', 'delinquent' or somewhere in-between - do not roll on deterministically to foregone conclusions.

It is not easy - and perhaps not helpful - therefore to apply orthodox risk assessments and predictions to lives like these. Experience of school disengagement, parental separation, low educational attainment, early offending and so on was widespread but the most serious forms of social exclusion - experienced as long-term criminal and drugusing careers - were limited to a minority. Conversely, economic marginality in late teenage and early adulthood - signified by recurrent episodes of 'poor work' and unemployment - was the preserve of all, despite differential levels of school engagement and educational qualification.

In conclusion, we stress the value of ethnography in understanding how young people experience risks as they grow up in poor neighbourhoods. At the same time, we should be wary of studies (of youth transitions in general, of criminal career in particular) that cease there. The Teesside studies emphasises how individual youth transitions must be understood in relation to changing, place-specific and unequal 'structures of opportunity'. They suggest an approach that situates the current academic and policy fascination with the twists and turns of individual careers and transitions within that panorama of social structural processes that create 'risk' and 'exclusion' - in some places, during some times, for some young people. 


\section{REFERENCES}

Armstrong, D. (2003) 'Pathways into and out of crime: risk, resilience and diversity', ESRC Research Priority Network conference, University of Sheffield.

Beinart, S., Anderson, B., Lee, S., and Utting, D (2002) Youth at Risk?, London: Communities that Care.

Beck, U. (1992) Risk Society, London, Sage.

Beck, U., Giddens, A., Lash, S. (eds.) (1994) Reflexive Modernization, Cambridge: Polity Press.

Becker, H. (1963) Outsiders, Glencoe, Free Press.

Berger, P., and Berger, B. (1972) Sociology: A Biographical Approach, New York, Basic Books.

Byrne, D. (1999) Social Exclusion, Milton Keynes: Open University Press.

Chamberlayne, P., Rustin, M., and Wengraf, T. (eds.) (2002) Biography and Social Exclusion in Europe, Bristol: Policy Press.

Cohen, P., and Ainley, P. (2000) 'In the country of the blind? Youth studies and cultural studies in Britain', Journal of Youth Studies, 3, 1: 79-95.

Coles, B. (1995) Youth and Social Policy, London: UCL Press.

--- (2000) Joined Up Youth Research, Policy and Practice, Leicester: Youth Work Press.

Craine, S. (1997) 'The Black Magic Roundabout', in MacDonald, R. (ed.) Youth, the 'Underclass' and Social Exclusion, London: Routledge. 
Crow, I., France, A., Hacking, S., and Hart, M. (2004) Does Communities that Care work? York: Joseph Rowntree Foundation.

Dennis, N. (1993) Rising Crime and the Dismembered Family, London: Institute of Economic Affairs.

DETR (2000) Index of Multiple Deprivation, London: Department of the Environment, Transport and the Regions.

Du Bois-Reymond, M. (1998) “'I don't want to commit myself yet': young people's life concepts", Journal of Youth Studies, 1, 1: 63-80.

EGRIS (European Group for Integrated Social Research) (2001) 'Misleading trajectories', in Journal of Youth Studies, 4, 1: 101-118.

ESRC (2004) Pathways into and out of crime, Sheffield: University of Sheffield.

Farrington, D. (1994) 'Human development and criminal careers', in Maguire, M., Morgan, R., and Reiner, R. (eds) Oxford Handbook of Criminology, Oxford: Oxford University Press.

--- (1996) Understanding and preventing youth crime, Joseph Rowntree Foundation Social Policy Findings 93, York: JRF.

Farrington, D., and Painter, K. (2004) Gender differences in offending, Home Office Online Report 09/04, London: Home Office.

Foster, J. (2000) 'Social Exclusion, Crime and Drugs', in Drugs: Education, Prevention and Policy (7), 4: 317-330.

France, A., (2000) 'Towards a sociological understanding of youth and the risk-taking', Journal of Youth Studies, 3, 3: 317-31. 
Furlong, A. and Cartmel, F. (1997) Young People and Social Change, London: Open University Press.

Giddens, A. (1990) The Consequences of Modernity, Cambridge: Polity Press.

--- (1991) Modernity and Self-identity Cambridge: Polity Press

Graham, J., and Bowling, B. (1995) Young People and Crime, Home Office Research Study 145, London: HMSO.

Hodkinson, P. and Sparkes, A. (1997) 'Careership: a sociological theory of career decision making', in British Journal of Sociology of Education, 18, 1, 29-44.

Home Office (2004) Confident Communities in a Secure Britain, CM 6287, London: Home Office.

Horsefield, A. (2003) 'Risk assessment: who needs it?', Probation Journal, 50, 4: 374-379.

Johnston, L., MacDonald, R., Mason, P., Ridley, L. and Webster, C., (2000) Snakes \& Ladders, Bristol: Policy Press

Jones, G. (2002) The Youth Divide, York: Joseph Rowntree Foundation.

Laub J., and Sampson, R. (2003) Shared Beginnings, Divergent Lives, Cambridge, Massachusetts: Harvard University

MacDonald, R., and Marsh, J. (2005) Disconnected Youth? Growing Up in Britain's Poor Neighbourhoods, Basingstoke: Palgrave,

Merton, B.(1998) Finding the Missing, Leicester: Youth Work Press.

Mitchell R., Shaw, M., and Dorling, D. (2000) Inequalities in Life and Death: What if Britain were more equal? Bristol: Policy Press. 
Mitchell, W., Bunton, R., and Green, E. (2004) Young People, Risk and Leisure, Basingstoke: Palgrave.

Muncie, J. (2004, second edition) Youth and Crime, London: Sage.

Roberts, K. (2000) 'The sociology of youth: problems, priorities and methods', $\underline{\text { British }}$ Sociological Association Youth Study Group Conference, University of Surrey, July.

Rutherford, A. (1992) Growing Out of Crime: the New Era, London: Waterside Press.

Sampson, R., and Laub, R. (1993) Crime in the Making, London: Harvard University Press.

Scott, J., and Chaudhary, C. (2003) Beating the Odds, Leicester: National Youth Agency.

Simpson, M. (2003) 'The relationship between drug use and crime', in International Journal of Drug Policy, 14: 307-319.

Smith, D., and McVie, S. (2003) 'Theory and method in the Edinburgh Study of Youth Transitions and Crime', British Journal of Criminology, 43: 169-195.

Social Exclusion Unit (1997) Tackling Truancy, London; Social Exclusion Unit.

Stephen D., and Squires, P. (2003) 'Adults Don't Realize How Sheltered They Are', Journal of Youth Studies, 6, 2: 145-164.

Thomson, R., Bell, R., Holland, J., Henderson, S., McGrellis, S., and Sharpe, S. (2002b) 'Critical moments: choice, chance and opportunity in young people's narratives of transition', Sociology, 36, 2: 335-354.

Webster, C. (2005) 'Predicting Criminal Careers Through Risk Assessment', British Society for Criminology Annual Conference, University of Leeds. 
Webster, C., Simpson, D., MacDonald, R., Abbas, A., Cieslik, M., Shildrick, T., and Simpson, M., (2004) Poor Transitions, Bristol: Policy Press.

Webster, C., MacDonald, R. and Simpson, M. (2006, forthcoming) 'Predicting criminality? Risk factors, neighbourhood influence and desistance', Youth Justice, 6, 1.

Wikstrom, P. (n.d.) Individual risk, life-style risk and adolescent offending, www.scopic.ac.uk, accessed $11^{\text {th }}$ March 2004.

Young, J. (1999) The Exclusive Society, London, Sage.

$\mathrm{rfm}$ /australia journal article 2005/ mar06/6.559 words 
